\title{
Media Poster Dan Film Sebagai Instrumen Propaganda Militer Jepang Di Indonesia 1942-1945
}

\author{
Gema Budiarto \\ Universitas Diponegoro \\ Corresponding author`s e-mail: history.gema@gmail.com
}

\begin{abstract}
This articles describes the use of poster and film which used by Japanese military during his occupation in Indonesia 1942-1945. Through the Japanese credo of Hakko Ichiu (/八紘一宇) and the doctrine of Dai Tōa Kyōeiken (大東亜共栄圏) or known as The Greater East Asia Co-Prosperity Sphere had to bring Japan into World War II Pacific Front. Early 1940's, Japan began moving to realize his ambitions by invading some territories in Asia that was occupied by western such as British in Malaya, France in France Indochina, The United States in Philippines, and Dutch in Indonesia. Japan did not only fight physical war but Japan was also doing the psychological war or propaganda. The most influential media used by Japan in the propaganda warfare were posters and films. The approach used in this research is historical method which has four steps among others are heuristics, critics, interpretation, and historiography. The results showed that propaganda media like poster and film that was made by Japanese military was effective to mobilize the people to be able to cooperate with the Japanese military to realize The Greater East Asia Co-Prosperity Sphere under the Japanese leader.
\end{abstract}

Keywords: Posters, Movies, Propaganda, Japan, Indonesia

Abstrak: Penelitian ini menelaah penggunaan media poster dan film yang digunakan oleh militer Jepang selama menduduki Indonesia 1942-1945. Melalui paham Hakkō Ichiu (/八紘一宇) dan doktrin Dai Tōa Kyōeiken (大東亜共栄圏) atau dikenal dikenal dengan sebutan Kemakmuran Bersama Asia Timur Raya harus membawa Jepang masuk dalam Perang Dunia II front Pasifik. Awal tahun 1940-an, Jepang mulai bergerak untuk mewujudkan cita-citanya dengan menginvasi wilayah-wilayah yang diduduki oleh bangsa-bangsa barat seperti Inggirs di Malaya, Perancis di Indonchina Perancis, Amerika Serikat di Filipina, dan Belanda di Indonesia. Tidak hanya melakukan perang secara fisik tetapi Jepang juga melakukan perang urat saraf atau perang propaganda. Media yang paling berpengaruh yang digunakan oleh Jepang dalam perang propaganda tersebut yakni media poster dan film. Metode yang digunakan dalam penelitian ini adalah metode sejarah yang terdiri dari empat tahapan diantaranya heuristik, kritik, interpretasi, dan historiografi. Hasil penelitian menunjukkan bahwa media propaganda poster dan film yang dibuat oleh militer Jepang efektif dalam memobilisasi rakyat untuk dapat bekerjasama dengan Militer Jepang demi terciptanya Kawasan Kemakmuran Asia Timur Raya di bawah pimpinan Jepang.

Kata kunci: Poster, Film, Propaganda, Jepang, Indonesia

\section{Pendahuluan}

Serangan Jepang pada awal Desember 1941 ke Malaya dan Pearl Harbor merupakan sebuah serangan pembukaan Jepang untuk menjalankan aksi imperialismenya di kawasan Pasifik Barat dan Asia Tenggara. Atas serangan tersebut, pernyataan resmi pun dikeluarkan oleh Presiden Franklin Delano Roosevelt pada 8 Desember 1941 (sehari setelah bencana di Pearl Harbor) yang mendeklarasikan perang melawan Jepang. Jepang sendiri mendeklarasikan perang terhadap Amerika Serikat pada 7 Desember 1941 (2 jam setelah serangan ke Pearl Harbor). Sedangkan sekutu Jepang di Eropa Jerman dan Italia 
mendeklarasikan perang terhadap Amerika Serikat pada 11 Desember 1941. Jerman dan Italia akan membentuk era baru di kawasan Eropa, sedangkan Jepang akan mengkontruksi era barunya di kawasan Asia Timur (Overy, 2010). Dalam serangannya ke salatan (wilayah Asia Tenggara) Jepang memiliki dua fase. Fase pertama yakni tugas dari Angkatan Darat Jepang ke-14 dan ke-25 untuk menguasai Filipina, Borneo Britania, dan Malaya. Dimana wilayah tersebut dignaban sebagai batu loncatan untuk fase yang kedua yakni menduduki Hindia Belanda. Fase kedua menargetkan kawasan Sumatera Selatan, Borneo Belanda, dan Sulawesi. Dari kawasan tersebut nantinya akan diarahkan menuju Jawa sebagai pusat pemerintahan Hindia Belanda (Groen, 2016). Guna membendung pergerakan Jepang yang semakin mendekati Jawa, sekutu membentuk pertahanan laut. Armada laut sekutu terlibat perang laut dengan armada Jepang pada 27 Februari 1942 di Laut Jawa. Pertempuran Laut Jawa ini dimenangkan oleh Jepang dan memudahkannya untuk melakukan pendaratan di Pulau jawa yang dipimpin oleh Letnan Jenderal Hitoshi Imamura Komandan Tentara ke-16 (Osamu Butai) (Notosusanto \& Djoened, 2008).

Beberapa hari setelah Jepang melakukan pendaratan di Jawa, pemerintah dan tentara Belanda menyerah pada 8 Maret 1942 yang ditandai dengan diadakannya Perjanjian Kalijati (Aziz, 2012; Mayer, 1984). Meskipun Belanda telah menyerah, usaha pembersihan pasukan Belanda dan sekutu berlangsung berbulan-bulan (Ricklefs, 2005). Seperti apa yang telah dicita-citakan Jepang yakni menjadi negara adi daya dan menyatukan seluruh Asia Timur. Melalui konsep tersebut, kedatangan Jepang ke Indonesia dengan membawa semboyan-semboyan nasionalisme, Pan Asia-isme, Asia untuk Asia, menentang imperialisme bangsa Barat, dan Jepang saudara tua bangsa Indonesia. Rakyat sangat antusias menyambut kedatangan Jepang yang dianggap sebagai pembebas. Kolonel Iwane Matsui dalam pidatonya mengatakan Nippon ke Indonesia untuk membela kehormatan Indonesia, peperangan yang dipimpin oleh Dai Nippon untuk membebaskan Asia dari imperialisme bangsa Eropa dan untuk kemakmuran Asia Timur Raya (Melati, 2012).

Meskipun Jepang telah menjadi penguasa tunggal di Indonesia, posisi Jepang masih tidak aman. Titik balik peperangan terjadi dalam pertempuran Midway pada 3-7 Juni 1942 yang menenggelamkan kapal induk Akagi, Kaga, dan Soryu. Dari pertempuran ini pasukan Jepang mulai mengalami kemunduran dan beberapa wilayah dapat dikuasai oleh sekutu. Pendudukan militer di Indonesia tidak hanya melakukan perang fisik tetapi juga perang melalui propaganda guna mempengaruhi rakyat agar bersedia membantu Jepang dalam perang terutama setelah mengalami kemunduran dibeberapa wilayah pasifik. Melalui propaganda, Jepang mempengaruhi penduduk wilayah tanah jajahannya untuk mendukung gerakan Jepang dengan dalih membebaskan negara-negara di Asia dari penjajahan Bangsa 
Barat. Propaganda merupakan aktivitas komunikasi yang bertujuan untuk mempengaruhi atau mengajak orang atau sekelompok orang (masyarakat) untuk melakukan suatu tindakan tertentu. Propaganda tersebut dapat dilakukan melalui media-media komunikasi, seperti: radio, surat kabar, gambar, poster, film, televisi, majalah, dan lain-lain. Senjata dalam perang tidak hanya berupa peluru, granat, senjata mesin, ataupun bom tetapi propaganda juga merupakan senjata dan instrumen penting dalam perang. Saking pentingnya propaganda menjadi perhatian utama bagi pihak yang terlibat perang. Propaganda melibatkan orangorang yang ahli dalam bidangnya seperti artisan atau pekerja seni, pembuat film, dan golongan intelektual. Poster dan film pada saat itu merupakan media yang paling sering digunakan dalam propaganda. Banyak poster-poster propaganda yang telah diterbitkan dan film-film propaganda yang telah ditayangkan dan secara keseluruhan berisi ajakan, himbauan, dan peringatan.

Poster dan film memiliki keunggulan masing-masing sebagai media propaganda. Poster merupakan media gambar yang didalamnya terkombinasi antara kata-kata dan gambar. Ada empat macam poster propaganda, yakni poster yang membawa pesan patriotisme, poster yang membawa pesan sentimental, poster yang mengandalkan humor untuk menyampaikan maksudnya, dan poster yang bermuatan negatif atau graphic violence (Mahaney, 2002). Pemilihan dan pemaduan gambar, warna, dan tulisan dalam media poster yang tepat dapat mempengaruhi sikap orang yang melihat. Sejalan apa yang dikatakan oleh Flaming dalam (Jonassen, 2004) berpendapat bahwa kata dan gambar/ilustrasi merupakan alat untuk menyampaikan pesan dibuat dengan tujuan untuk memodifikasi psikomotorik, kognitif, atau perilaku afektif seseorang. Selain itu poster juga mudah digandakan dan dibuatnya, dan dapat menjangkau semua kalangan.

Film juga memiliki peran yang penting dalam menyebarkan propaganda. Film sendiri merupakan salah satu media komunikasi yang memiliki pengaruh besar dan juga memiliki peran dalam memanipulasi pola fikir, tindakan, serta sikap masyarakat. Film memiliki kekuatan dan kapasitas untuk menjangkau seluruh lapisan sosial, oleh sebab itu memungkinkan para film maker atau pembuat film memiliki kesempatan untuk mempengaruhi masyarakat (Sobur, 2001). Film yang dirancang dengan sangat baik dapat membawa emosi penonton yang melihat. Hal ini sejalan dengan penelitian yang dilakukan oleh Philippot dalam (Gross \& Levenson, 1995), bahwa film memunculkan enam kondisi emosional seperti geli, marah, jijik, takut, netral, dan sedih. Karena dapat mempengaruhi emosi, maka dari itu wajar jika film dimanfaatkan sebagai media propaganda. Bertitik tolak dari pemaparan yang telah dijelaskan di atas, tulisan ini bertujuan untuk mengidentifikasi 
penggunaan media poster dan film propaganda pendudukan militer Jepang di Indonesia serta dampaknya terhadap masyarakat.

\section{Metode}

Penelitian ini menggunakan metode penelitian sejarah. Metode sejarah memiliki empat tahapan yakni heuristik (pengumpulan sumber), kritik atau verifikasi (melakukan kritik sumber), intepretasi (menafsirkan) dan historiografi (penulisan) (Kuntowijoyo, 2005). Tahap heuristik, pada tahapan ini dilakukan pengumpulan sumber-sumber primer dan sekunder. Sumber primer didapat dari arsip Netherlands Institute of War Documentation (NIOD), koleksi pribadi Majalah Berita Pemerintah Jepang Kan Pō, dan National Library of Australia, sedangkan sumber sekunder didapat dari buku, majalah, artikel ilmiah, dan lainlain. Tahap verifikasi dilakukan dengan cara melakukan kritik terhadap sumber-sumber baik primer maupun sekunder yang telah didapat. Tahap berikutnya yakni menafsirkan faktafakta yang telah didapat dari sumber-sumber yang diverifikasi dan setelah itu melanjutkannya pada tahap penulisan atau historiografi.

\section{Hasil Dan Pembahasan}

\section{A. Tumbuhnya Semangat Imperialisme}

Paham Hakko Ichiu (/八紘一宇) yang mengajarkan bahwa, seluruh dunia harus disatukan dan dipimpin oleh bangsa Jepang, sehingga Jepang memiliki hasrat kuat untuk menguasai wilayah-wilayah yang berada di kawasan Asia. Hakko Ichiu memiliki makna "delapan sudut dunia di bawah satu atap" atau bisa juga diartikan "empat sudut dan empat dinding di bawah satu atap" merupakan ajaran dari agama Shinto yang diperintahkan oleh Kaisar Jimmu (Kaisar pertama Jepang) (Yenne, 2014; Edwards, 2003). Sesuai dengan pendapat dari Tanaka Chigaku, seseorang yang mempopulerkan gagasan Hakko Ichiu,

“... claimed that Jimmu, the human descendant of Japan's chief deity the sun Goddess Amaterasu-no-mi-kami, had uttered the phrase as he ascended to become Japan's firs emperor... Jimmu had prophesized that Japan's pure Shinto morality would expand to encompass the entire world" (Perez, 2013).

Tanaka Chigaku adalah penganut Budha aliran Nichiren. Tanaka Chigaku adalah seorang orator, penulis, dan seorang propagandis ultra-nasionalis pada zaman Meiji, Taisho, dan awal Showa. Ide inilah yang membuat Jepang berusaha keras untuk mendominasi wilayah Asia Timur pada tahun 1930-an bahkan wilayah Asia Tenggara dan Pasifik Barat, dengan harapan akan menciptakan Kemakmuran Bersama Asia Timur Raya di bawah pimpinan Jepang atau lebih dikenal dengan sebutan Dai Tōa Kyōeiken (大東亜共栄圏). Jepang merupakan salah satu dari tiga negara fasis (Jepang, Jerman, dan Italia) pada masa Perang 
Dunia II. Aliansi tiga negara tersebut dikukuhkan dalam Pakta Tripartite yang ditandatangai pada 27 September 1940 di Berlin dan disaksikan oleh masing-masing perwakilan tiga negara, diantaranya: Saburo Kurusu (Jepang), Galeazzo Ciano (Italia) dan Adolf Hitler (Jerman). Isi dalam perjanjian tersebut yaitu: saling mengakui kepemimpinan tiga negara tersebut di wilayahnya masing-masing, untuk Jepang memimpin di Asia dan Jerman dan Italia memimpin di Eropa dan kerjasama dan saling membantu antar tiga negara tersebut dalam bidang politik, ekonomi, dan militer. Jepang, Jerman, dan Italia memiliki pandangan fasisme dalam gerakannya. Fasisme merupakan pandangan politik yang absolut, pemimpin memiliki kuasa mutlak tanpa batasan dan berkuasa secara totaliter dan memiliki sifat fanatik yang banga dengan bangsanya sendiri sehingga menimbulkan kesetiaan ekstrim dan memandang bahwa bangsa lain rendah (chauvinism).

Fasis memiliki tujuh unsur ajaran pokok, antara lain: (a) ketidakpercayaan terhadap kemampuan nalar; (b) penyangkalan terhadap persamaan manusia; (c) kode perilaku yang didasarkan pada kekerasan; (d) pemerintahan oleh kelompok elit; (e) sistem totaliter; (f) rasialisme dan imperialism; dan (g) menjadi pihak oposisi dalam hukum dan aturan internasional (Ebenstein, 1963). Serangan Jepang ke Semenanjung Malaya mengawali Perang Dunia II di kawasan Asia Pasifik (Kurasawa, 2016). Gempuran Jepang di Semenanjung Malaya tepatnya di Kota Bharu terjadi sebelum pesawat terbang dan armada Amerika Serikat di Pearl Harbor dihancurkan oleh Jepang. Armada kapal perang Jepang menembakkan meriamnya di Kota Bharu pada tengah malam sekitar pukul 01.15 atau pukul 05.45 waktu Hawaii, dan pada waktu yang bersamaan pula kapal induk Jepang yang tergabung dalam Kido Butai masih bersiap-siap akan meluncurkan pesawat-pesawatnya untuk menyerang Pearl Harbour (Redaksi Angkasa, 2008).

Armada kapal induk Jepang menerbangkan 350 pesawat yang mengemban misi untuk menghancurkan Pearl Harbor. Kode Tora! Tora! Tora! di komandokan oleh Mitsuo Fuchida kepada Laksamana Nagumo, yang menandakan serangan dadakan berhasil dijalankan. Torpedo dan bom ditembakkan ke kapal tempur, kapal perusak, dan pesawat terbang Amerika Serikat. Jepang tidak membutuhkan waktu lama untuk menghancurkan kekuatan militer Amerika Serikat di Pasifik (Gorman, 2009). Kemenangan Jepang di Semenanjung Malaya dan Pearl Harbor membuka jalan untuk menguasai wilayah-wilayah di kawasan Asia Tenggara termasuk Indonesia. Serangan atas Pearl Harbor, Filipina, dan Malaya oleh Militer Jepang membuat pihak sekutu tidak bisa berbuat apa pun dengan besarnya kekuatan Jepang. Militer Jepang berhasil dengan baik dan dalam waktu yang singkat dapat mengusai wilayah Asia Tenggara yang sangat luas (Ham, 1989). Pada tanggal 28 Februari hingga menjelang tanggal 1 Maret 1942, Tentara Ke-16 Jepang berhasil mendarat di tiga 
tempat sekaligus (pantai barat laut Banten, kawasan Eretan Wetan, dan Kargan). Namun, pendaratan Jepang ini dilawan dengan keras oleh Amerika Serikat, Belanda, Inggris, dan Australia (The Sydney Morning Herald, Japanese Invade Java at Three Points, Edisi Senin 2 Maret 1942, Lembar ke-1 dan ke-5).

\section{B. Pasukan Jepang Merebut Jawa}

Pulau Jawa sebagai pusat administrasi Hindia-Belanda pada saat itu memiliki peran yang sangat penting. Oleh karena itu untuk merebut Hindia-Belanda secara keseluruhan, maka harus menaklukkan Jawa sebagai jantung pemerintahan. Sebelum melakukan pendaratan, unit pasukan udara Jepang terlebih dahulu melakukan serangan terhadap lapangan udara di Jawa untuk melumpuhkan kekuatan udara sekutu. Unit udara Jepang diberangkatkan dari Kendari dan Balikpapan yang bertugas untuk menghancurkan lapangan udara sekutu di Surabaya. Rencana pengeboman dirancang oleh Laksamana Nishizō Tsukahara dari Unit Udara Gugus Tugas Selatan. Sebelum serangan dilakukan Unit Serangan Udara ke-2 Jepang melakukan pengintaian di Surabaya, Malang, dan Madiun. Pada tanggal 3 Februari 1942, pasukan udara Jepang melakukan serangan udara di Surabaya pada pukul 12.20, Madiun pada pukul 12.25, dan Malang pada pukul 12.10 (Remmelink, 2018). Pada tanggal 1 Maret 1942, Jepang berusaha untuk menguasai Bandung dengan mendaratkan satu detasemen dengan kekuatan 5.000 personil yang dipimpin oleh Kolonel Toshinori Shoji. Pasukan tersebut berhasil menguasai wilayah Subang dan Kalijati. Tentara Belanda pun beberapa kali berusaha untuk merebut Subang dan Kalijati tetapi usahanya gagal dan ratusan pasukan Belanda banyak menjadi korban. Pada tanggal 5 Maret 1942, Jepang bergerak menyerbu Bandung. Pasukan Belanda membangun pertahanan terakhir di Lembang, tetapi pada 7 Maret 1942 Lembang pun dapat dikuasai Jepang.

Pasukan Belanda di sekitar Bandung meminta penyerahan lokal, Kolonel Shoji menyampaikan usul penyerahan tersebut kepada Jenderal Imamura, tetapi tuntutan Jenderal Imamura menginginkan penyerahan total semua pasukan sekutu yang ada di jawa. Pihak Jepang memberikan ultimatum, jika pihak Belanda tidak menuruti permintaan tersebut, maka kota Bandung akan dibom dari udara. Jenderal Imamura juga menuntut Gubernur Jenderal Belanda harus turut dalam perundingan di Kalijati. Pada pukul 17.00 tanggal 8 Maret 1942, Gubernur Jenderal Tjarda van Starkenborgh dan Panglima Tentara HindiaBelanda serta beberapa pejabat tinggi militer dan seorang penerjemah pergi ke Kalijati. Dalam perjanjian Kalijati, Letnan Jenderal Ter Poorten bersedia menerima tuntutan Jenderal Imamura, sebaliknya Tjarda menolak dengan alasan Bandung adalah kota terbuka. Perundingan tersebut dilakukan tanpa Tjarda, sehingga tuntutan Jenderal Imamura yakni, kapitulasi tanpa syarat Angkatan Perang Hindia Belanda kepada Jepang. Letnan Jenderal Ter 
Poorten (Belanda) dan Letnan Jenderal Imamura (Jepang) menyepakati dan menandatangani dokumen penyerahan tanpa syarat yang disusun dalam bahasa Jepang dan bahasa Belanda. Penandatanganan ini dilakukan pada pukul 13.20 dihari yang sama. Pada awal pendudukan militer Jepang menerapkan pemerintahan sementara guna menjaga kestabilan hingga dibentuknya pemerintahan tetap. Berikut ini garis besar pokok regulasi tata negara awal pendudukan Jepang:

1. Militer Jepang melangsungkan pemerintahan sementara agar mendatangkan keamanan.

2. Pembesar Balatentara Nippon memegang kekuasaan Pemerintahan Militer yang tertinggi.

3. Badan, hukum, dan undang-undang dari pemerintahan sebelumnya masih diakui selama tidak bertentangan dengan aturan militer Jepang.

4. Semua pegawai dan penduduk sipil diwajibkan tunduk pada perintah militer Jepang dan para pembesar pemerintahan militer Jepang (Kan Pō, Nomor Istimewa, 7-3-2602/1942).

Setelah dirasa cukup, pemerintah pendudukan militer Jepang mengakhiri pemerintahan sementara yang dibuat sebelumnya dan pendudukan militer Jepang pun meningkatkan pemerintahannya menjadi pemerintahan tetap atau permanen dengan dikeluarkannya UU No. 27 (tentang perubahan tata pemerintahan daerah) dan UU No. 28 (tentang aturan pemerintahan Syū dan Tokubetsu Syi) (Kan Pō, Nomor 1, Tahun ke-1, Bulan 8-2602/1942).

\section{Media Poster sebagai Alat Propaganda}

Propaganda memiliki sejarah lama yang terkait dengan masalah perpolitikan di suatu kerajaan. Pada tahun 1622 Vatican mencetuskan Sacra Congregatio de Propaganda Fide, yang memiliki pengertian Jemaat suci penyebar iman Gereja Katolik Roma. Propaganda yang dilakukan oleh Gereja Katolik Roma memiliki misi untuk menyebarkan iman dalam tatanan dunia baru dan menentang ajaran protestan. Propaganda memiliki persamaan makna seperti: kebohongan atau penipuan, penyimpangan (memutarbalikkan), manipulasi, mengendalikan pemikiran, perang psikologis, cuci otak, dan bujukan. Propaganda identik dengan agenda perpolitikan yang memiliki tujuan untuk mempengaruhi orang atau kelompok agar mempercayai suatu berita/peristiwa demi terciptanya suatu tujuan atau kepentingan politik tertentu. Propaganda tersebut bersifat persuasive, yakni ditujukan kepada orang atau pihak lain agar bersedia untuk mengakui, menerima, dan meyakini suatu ajaran, paham, atau peristiwa. Menurut Leonard W. Doob, propaganda berarti upaya untuk mempengaruhi dan mengontrol perilaku individu terhadap suatu tujuan dalam masyarakat pada waktu tertentu. Alex Carey menjelaskan pengetian propaganda, yakni komunikasi di mana bentuk dan isi telah dipilih dan ditentukan terlebih dahulu dengan tujuan untuk 
membawa seseorang tersebut mengadopsi sikap dan meyakini isi dalam komunikasi tersebut (Jowett \& O'donnell, 2018). Media berasal dari kata dasar Medium yang memiliki pengertian perantara atau pengantar suatu pesan dari pengirim ke penerima. Menurut Association of Education and Communication Technology / AECT, media adalah segala bentuk dan saluran yang digunakan untuk menyalurkan pesan/informasi kepada seseorang. National Education Association / NEA, berpendapat bahwa media merupakan bentuk komunikasi yang berbentuk visual maupun audiovisual, syarat media tersebut harus dapat dilihat, dibaca, didengar, dan mudah dipahami (Sadiman, 1993). Dapat disimpulkan bahwa media adalah alat untuk menyalurkan informasi atau pesan dari pihak satu ke pihak yang lain atau dari pengirim ke penerima, jika media tersebut merupakan media massa maka memiliki tujuan untuk memberikan informasi sehingga dapat mempengaruhi masyarakat luas. Menurut (Cangara, 2000), media massa memiliki karakteristik: bersifat melembaga, satu arah, meluas dan serempak, memakai peralatan teknis dan mekanis (radio, surat kabar, film, poster, televise, dan lain-lain), dan bersifat terbuka.

Propaganda memegang peranan penting. Menurut Aiko Kurasawa, Jepang meniru Jerman dalam membangun propaganda. Di Jerman ada suatu instansi yang bernama Pasukan Kebudayaan yang dipimpin oleh Menteri Propaganda Jerman, Joseph Goebbels. Instansi ini bertugas menjalankan propaganda terhadap pihak musuh dan pihak masyarakat Jerman sendiri. Sedangkan di Indonesia dibangun Departemen Propaganda (Sendenbu) yang merupakan bagian dari Gunseikanbu (Direktorat Jenderal Kebudayaan, 2018). Golongan yang utama mendapat perhatian dari Pemerintah Jepang adalah golongan pemuda. Jepang lebih terfokus pada golongan pemuda karena dianggap memiliki sifat yang giat, penuh semangat, dan biasanya masih diliputi idealisme. Oleh karena sifat yang demikian, propaganda Jepang akan mudah untuk ditanamkan. Media propaganda Jepang saat menjajah Indonesia bermacam-macam bentuknya, seperti: gambar/poster, film, radio, nyanyian/lagu, Kamishibai, tarian, wayang, dan drama. Dalam artikel ini akan dijelaskan propaganda Jepang melalui media gambar/poster dan film.

Jepang menggunakan media gambar/poster memiliki maksud tertentu, karena pada waktu itu banyak dari penduduk Indonesia masih belum bisa membaca, meskipun ada itu pun hanya sedikit, sehingga media poster dan film dianggap efektif untuk mempengaruhi penduduk agar menerima dan membantu Jepang. Meskipun poster juga terdapat sebuah tulisan, tulisan tersebut ringkas, padat, dan jelas sehingga dapat dengan mudah dipahami. Tulisan dalam poster tidak sebanyak dan tidak sedetail tulisan dimedia propaganda lain seperti surat kabar atau majalah. Berikut ini adalah beberapa dari gambar/poster propaganda yang dibuat oleh Jepang beserta penjelasannya. 


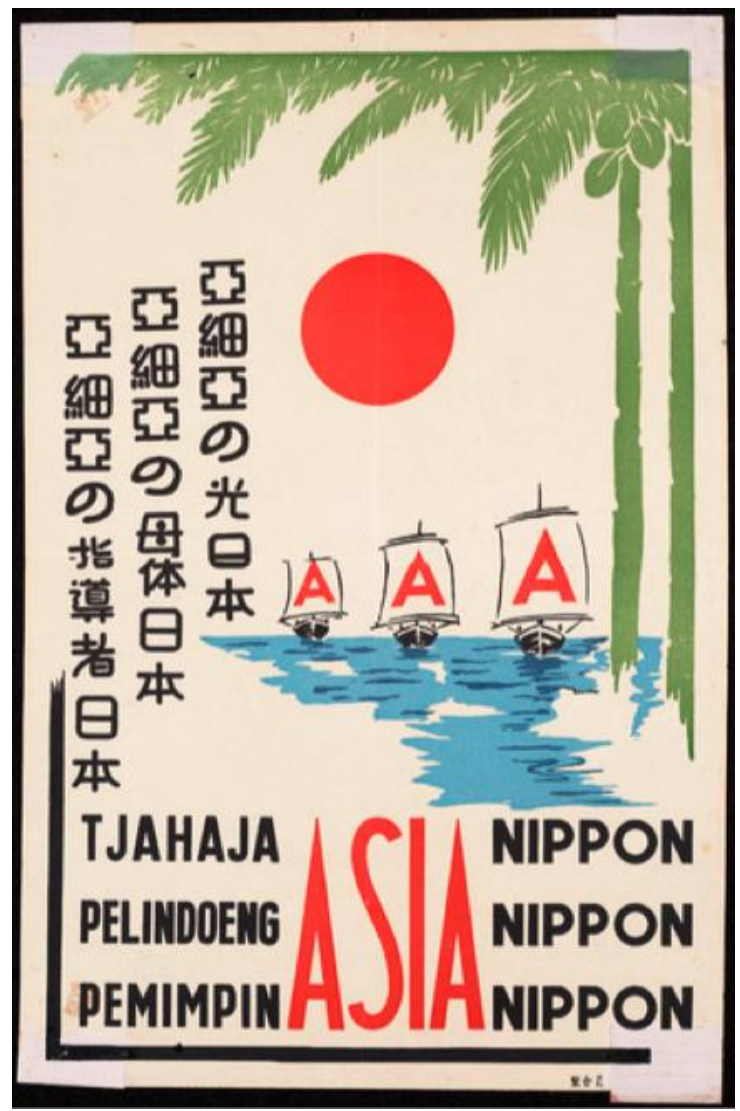

Gambar 1. Poster Propaganda 3A

(NIOD Instituut voor Oorlogs-, Holocausten Genocidestudies)

Gerakan 3A (AAA) yang memiliki kepanjangan Jepang Cahaya Asia, Jepang Pelindung Asia, Jepang Pemimpin Asia, merupakan suatu gerakan propaganda yang dibuat oleh Jepang. Gerakan 3A memiliki tujuan dasar untuk memanfaatkan tenaga-tenaga rakyat agar mau membantu Jepang dalam perang Asia Timur Raya. Gerakan ini juga menanamkan sentiment anti bangsa Barat, seperti Belanda, Inggris, dan Amerika Serikat. Mr. Samsuddin sebagai pemimpin Gerakan 3A juga berpendapat bahwa orang Barat telah berabad-abad lamanya menjajah Asia sehingga rakyat menderita. Berkat Jepanglah penjajahan itu berhasil dihapuskan (Notosusanto \& Djoened, 2008). Tetapi, gerakan ini tidak begitu efektif untuk mewujudkan misi-misi Jepang, akhirnya pada tahun 1943, Gerakan 3A dibubarkan. Djawa Hokokai (ジャワ奉公会/Jawa hōkō-kai) atau disebut juga dengan Perhimpunan Kebaktian Jawa, sedangkan di dalam poster bertuliskan Himpunan Kebaktian Rakyat, dibentuk pada 1944 atas pengganti PUTERA (Pusat Tenaga Rakyat). Gerakan PUTERA digantikan karena Jepang menyadari bahwa gerakan tersebut tidak membawa dampak baik bagi Pemerintah Jepang, tetapi lebih menguntungkan pihak dari Indonesia. Adanya gerakan Djawa Hokokai 
diharapkan agar rakyat dapat melaksanakan pengabdian atau baktinya (奉公精神/Hōkō seishin), pengabdian rakyat melalui tenaga dan usaha-usahanya yang lain sangat dibutuhkan oleh Pemerintah Jepang dalam rangka perang di kawasan Asia Timur, tetapi Pemerintah Jepang berdalih usaha-usaha rakyat ditujukan untuk memperkokoh pembelaan tanah air. Djawa Hokokai menampung beberapa organisasi-organisasi lain dibawahnya. Djawa Hokokai dalam struktur birokrasi berada langsung di bawah Pemerintah Jepang atau Gunseikan. Dalam poster Djawa Hokokai tertulis sedikit penjelasan tentang arti pentingnya kebaktian kepada Pemerintah Jepang,

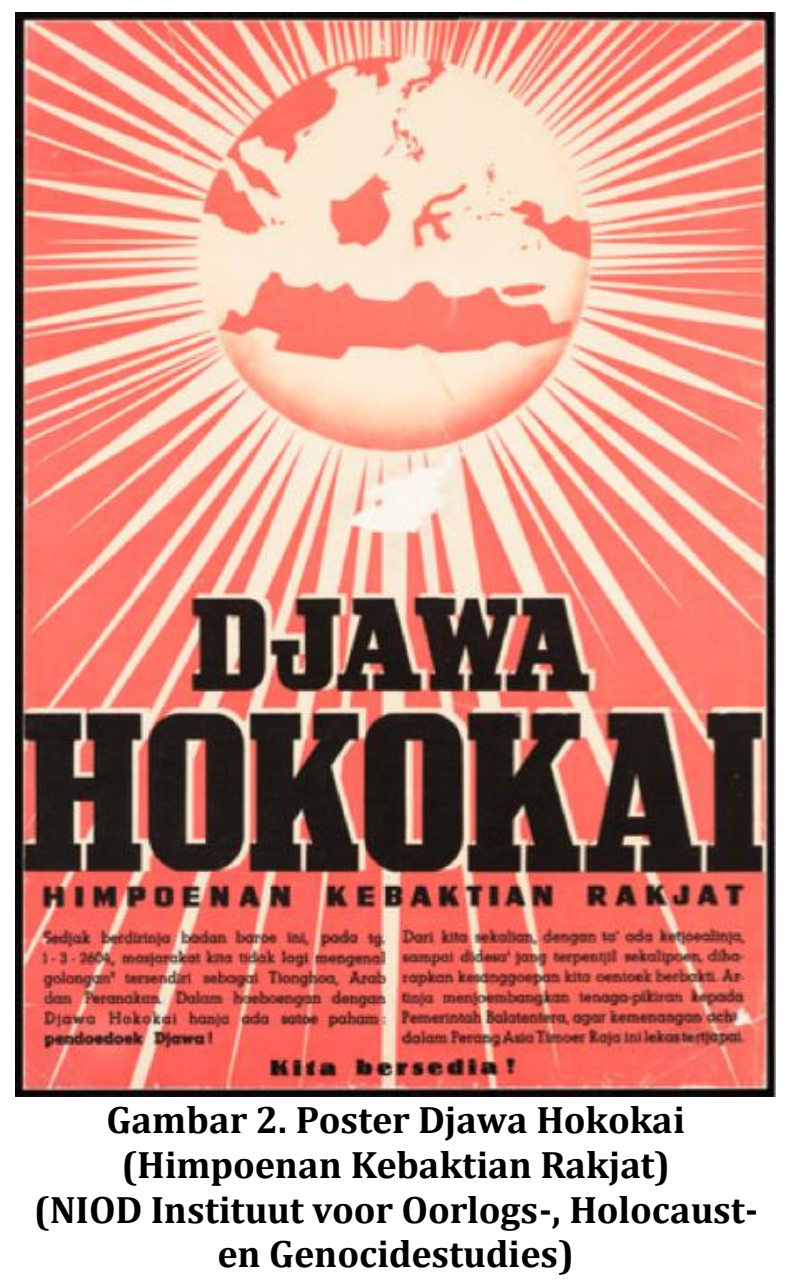

"Sedjak berdirinja badan baroe ini, pada tg. 1.3. 2604, masjarakat kita tidak lagi mengenal golongan ${ }^{2}$ tersendiri sebagai Tionghoa, Arab dan Peranakan. Dalam hoeboengan dengan Djawa Hokokai hanja ada satoe paham pendoedoek Djawa! Dari kita sekalian, dengan ta' ada ketjoealinja, sampai didesa ${ }^{2}$ jang terpentjil sekalipoen, diharapkan kesanggoepan kita oentoek berbakti. Artinja menjoembangkan tenaga-pikiran kepada Pemerintah Balatentera, agar kemenangan achir dalam Perang Asia Timoer Raja ini lekas tertjapai. Kita bersedia! 


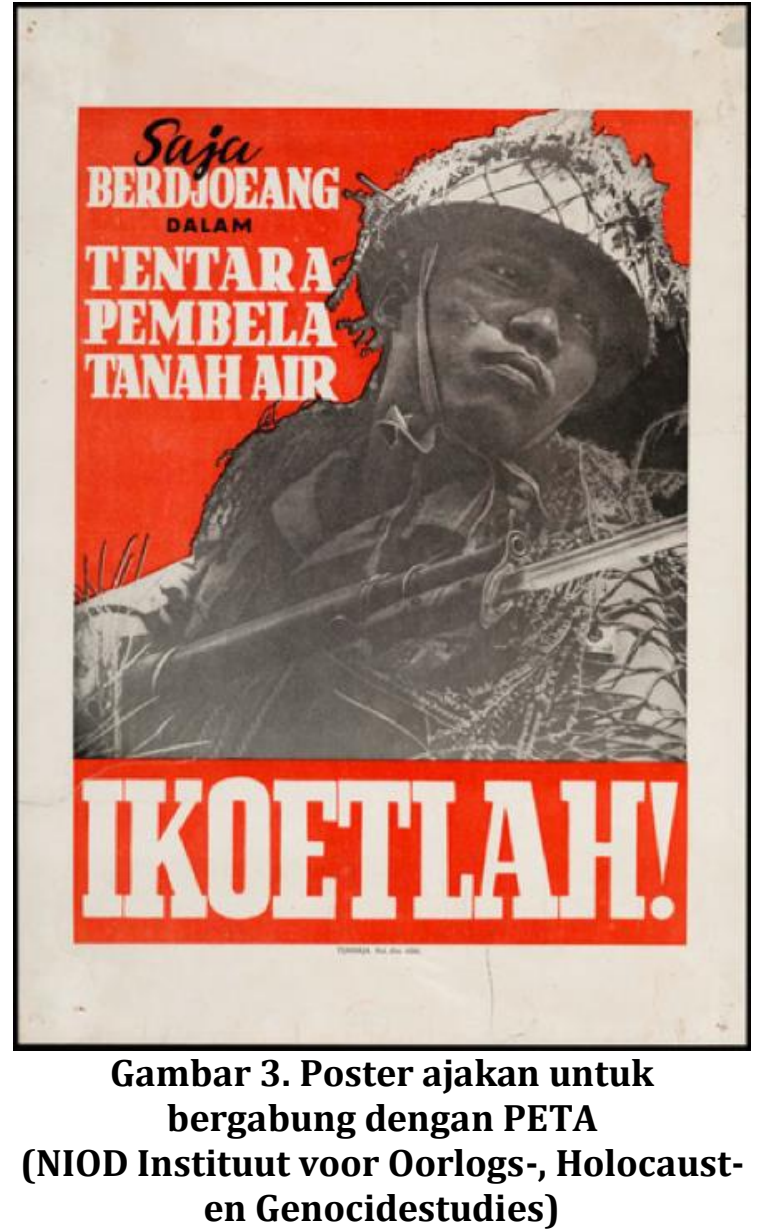

Tentara Sukarela Pembela Tanah Air (Peta) atau Tentara Relawan Pertahanan Lokal (郷土防衛義勇軍/Kyōdo bōei giyūgun) didirikan pada 3 Oktober 1943, Peta dibentuk atas dasar inisiatif Pemerintah Militer Jepang untuk kepentingannya dalam Perang Asia Timur Raya. Letnan Jenderal Kumakichi Harada memutuskan agar kesannya Peta adalah bentukan Indonesia, maka dicarilah seorang Indonesia yang berjiwa nasionalis, dia adalah Gatot Mangkupradja. Pemerintah Militer Jepang meminta agar Gatot Mangkupradja membentuk tentara yang anggotanya adalah orang-orang Indonesia. Atas saran dari Pemerintah Militer Jepang tersebut, pada tanggal 7 September 1943 mengirimkan surat permohonan pada Pemerintah Militer Jepang dan permohonannya dikabulkan dengan dikeluarkannya peraturan Osamu Seirei No. 44 pada tanggal 3 Oktober 1943. Peraturan ini menetapkan dibentuknya Tentara Peta secara formal. Terdapat lima macam kepangkatan dalam Peta, diantaranya adalah: daidancho (komandan battalion), chudancho (komandan kompi), shodancho (komandan peleton), budancho (komandan regu), dan giyuhei (prajurit sukarela). Peta sendiri difungsikan untuk membela tanah air dari serangan tentara Sekutu yang juga merupakan lawan dari Jepang pada saat itu. Hal senada juga diungkapkan oleh Suwondo (2011), 
"Pembentukan tentara PETA merupakan langkah Jepang untuk menghadapi serangan pasukan Sekutu yang semakin ofensif. Tentara PETA dibentuk sebagai pertahanan lokal. Kekalahan Jepang di Midway oleh pasukan Sekutu pada 1942 merubah strategi perang Jepang yang awalnya ofensif menjadi defensif. Sebagian tentara Jepang ke-16 dan ke-25 di Jawa dan Sumatera dikirim ke front Pasifik Selatan. Dikirimnya sebagian pasukan Jepang itu harus merencanakan pertahanan lokal dengan memanfaatkan penduduk untuk menghalau pendaratan Sekutu".

Perhatian masyarakat terhadap Peta ternyata besar dan antusias, terutama pemuda yang mendapat pendidikan sekolah menengah dan tergabung dalam Seinendan (barisan pemuda). Saat seluruh wilayah Hindia-Belanda diduduki Militer Jepang dan, berkat intelijen Jepang yang handal, masyarakat menganggap bahwa Jepang sebagai pembebas dari penjajahan Belanda. Setelah rakyat meyakini kehebatan Jepang, aksi propaganda pun dimulai Jepang dengan memberikan gambaran bahwa negara sekutu seperti Amerika Serikat, Inggris dan Belanda adalah negara penjajah dan musuh yang harus dilawan. Sehingga Jepang mampu mengobarkan nasionalisme rakyat. Pihak Jepang memperhatikan kualitas SDM dalam membentuk dan menyaring calon tentara Peta dan yang paling utama memiliki jiwa nasionalisme tinggi. Anggota Daidancho dipilih dari kalangan tokoh masyarakat yang terkemuka secara jabatan atau pemimpin agama, Cudancho dipilih dari pegawai negeri seperti guru, Shodancho dipilih dari pelajar (SMP, SMT, MULO, AMS, dan sekolah guru) dan untuk Budancho dan Giyuhei dipilih pemuda tingkat sekolah dasar. Khusus untuk perwira dididik di Seinen Dojo (tempat latihan pemuda) di Tangerang pada tanggal 23 Januari 1943, sekaligus menjadi suatu percobaan apakah pemuda pribumi memiliki kemampuan mental dan fisik untuk menjadi militer menurut aturan dan tata cara Jepang. 

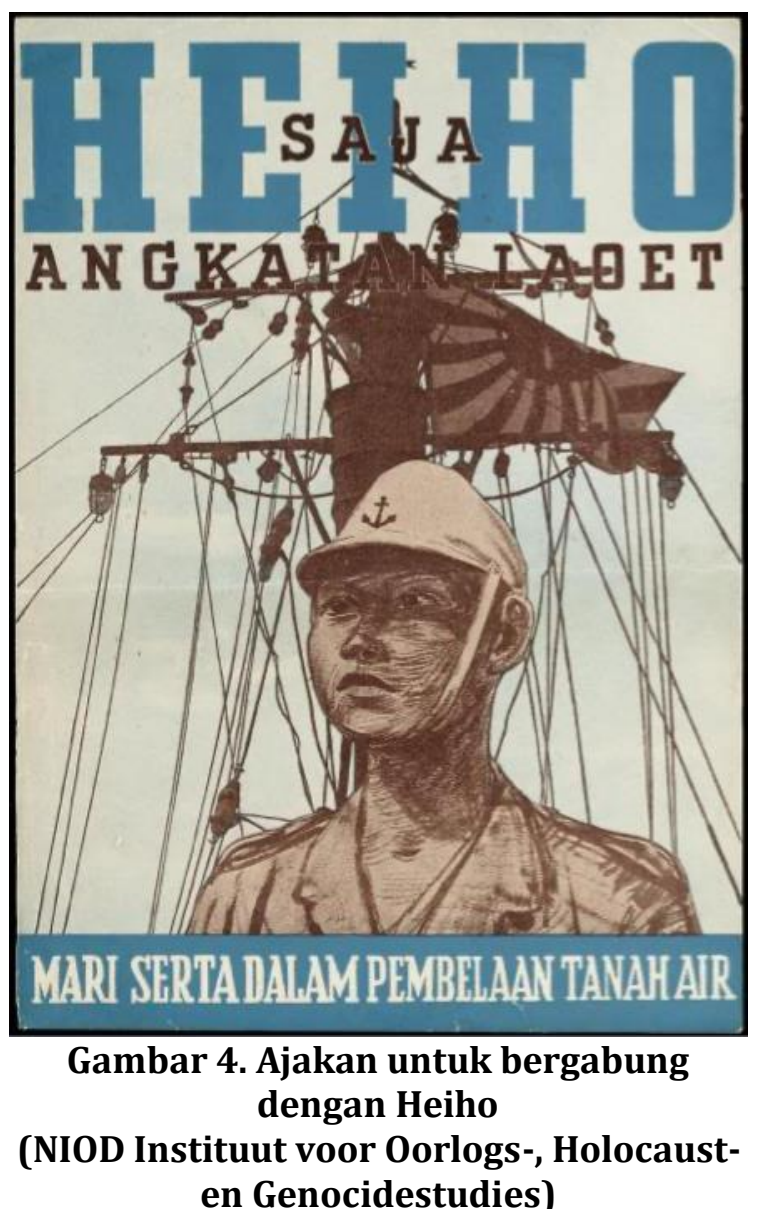

Sedangkan di wilayah Bogor mendapat pelatihan di lembaga yang bernama Jawa Boei Giyugun Kanbu Renseitai (Korps Latihan Pemimpin Tentara Sukarela Pembela Tanah Air di Jawa) yang kemudian berganti nama menjadi Jawa Boei Giyugun Kanbu Kyoikutai (Korps Pendidikan Pemimpin Tentara Sukarela Pembela Tanah Air di Jawa). Setelah selesai mengikuti pendidikan, anggota Peta ditempatkan di dalam daidan (Batalion) yang terdapat di wilayah Jawa-Madura dan Bali. Pembela tanah air di Jawa dan Bali dikenal dengan sebutan Peta, maka di wilayah Sumatera disebut Giyugun (Tentara Sukarela) (Poesponegoro, n.d.). Hal tersebut juga dijelaskan oleh Yoshimi Yoshiaki yang memaparkan pemerintahan Militer Jepang di Sumatera, "to protect the Japanese armed forces, Homeland Defense Auxiliary Army (Kyodo boei giyugun) units were established" (Yoshiaki, 2015). Heiho (兵補/Heiho) atau Pasukan Pembantu adalah satuan militer yang dibentuk oleh Pemerintahan Militer Jepang yang anggotanya merupakan orang-orang Indonesia. Tujuan dibentuknya Heiho juga sama dengan PETA, yakni membantu Jepang dalam kancah Perang Asia Timur Raya. Heiho dan Peta memiliki latarbelakang militer, tetapi antara keduanya memiliki perbedaan. Heiho merupakan prajurit lokal yang langsung membantu prajurit Jepang dalam peperangan, awalnya istilah membantu disini adalah sebagai tenaga pembantu kasar yang tidak diberi 
senjata, tetapi setelah Jepang terdesak oleh pasukan Sekutu, anggota Heiho juga turut serta dalam perang dibarisan depan bersama dengan prajurit Jepang (pemegang senjata antipesawat terbang, tank, artileri medan, dan pengemudi) dan biasanya anggota Heiho dikirim ke luar negeri seperti di Burma, Semenanjung Malaya, dan di wilayah lain yang sekiranya wilayah tersebut diduduki oleh Militer Jepang atau dalam kondisi perang, sedangkan Peta adalah prajurit lokal yang disiagakan disuatu daerah untuk mengantisipasi jika pasukan Sekutu suatu saat menyerang. Heiho dibentuk pada tanggal 2 September 1942 dan mulai melakukan perekrutan tentara pada 22 April 1943 atas usulan dari Komandan Tetinggi wilayah militer di Saigon. Heiho juga terbagi dalam masing-masing kesatuan, seperti kesatuan angkatan darat dan kesatuan angkatan laut. Menurut beberapa pendapat dari orang Jepang, angota Heiho lebih terlatih di dalam bidang militer daripada tentara Peta, karena anggota Heiho ditempatkan langsung di medan pertempuran.
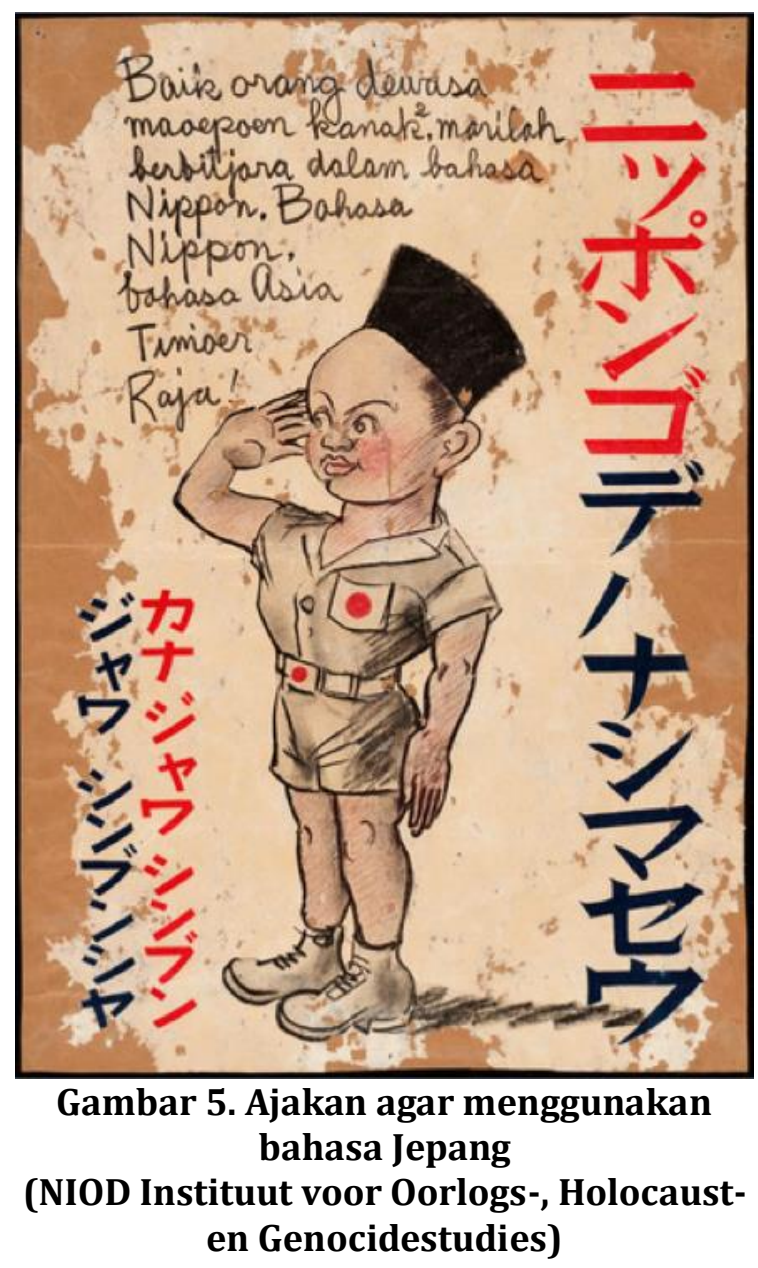

Salah satu dampak kekalahan Belanda oleh Militer Jepang adalah lenyapnya bahasa Belanda dari dunia pendidikan dan komunikasi harian di wilayah Hindia-Belanda dan digantikan dengan bahasa Jepang. Sejak saat itu pula, pemakaian bahasa Belanda dilarang keras, siapa pun yang masih menggunakan bahasa Belanda akan dituduh membantu musuh 
(Belanda, Amerika Serikat, dan Inggris). Kerasnya larangan pemakaian bahasa Belanda menuntut agar semua toko, rumah makan, perusahaan, perkumpulan dan lainnya yang memakai bahasa Belanda harus diganti dengan bahasa Indonesia atau bahasa Jepang. Sekolah-sekolah yang awalnya ditutup oleh Jepang dan dibuka kembali, mewajibkan bahasa Jepang dalam pengajarannya, dan bahasa Jepang/Nihongo termasuk dalam empat pelajaran utama (latihan kemiliteran/Kyoren, pelajaran moral/Shushin, pelajaran praktis/Sagyo) yang ditekankan dalam kurikulum. Jepang memiliki keinginan untuk mengajarkan bahasa Jepang kepada khalayak seluas mungkin, seperti di koloninya Taiwan dan Korea, pendidikan sekolah sepenuhnya diberikan dalam bahasa Jepang. Di Taiwan dan Korea, Pemerintah Jepang memiliki tujuan untuk "menjepangkan" penduduknya (Kurasawa, 2015). Tetapi, berbeda di wilayah Jawa dan sekitarnya, bahasa Jepang digunakan untuk memahami kehidupan, semangat, dan kebudayaan Jepang. Bahasa Jepang diajarkan di sekolah-sekolah dalam segala jenjang, untuk mengajarkan bahasa Jepang di sekolah lanjutan, maka Pemerintah Militer Jepang mengirim guru-guru dari Jepang. Guru tersebut direkrut dan dilatih oleh Kementerian Pendidikan Jepang. Mereka tidak hanya mengajar bahasa Jepang di sekolah, tetapi juga di sekolah bahasa Jepang (kursus) yang terbuka untuk umum.

\section{Propaganda Jepang dalam Media Film}

Propaganda melalui media film juga sangat gencar dilakukan Jepang dan Departemen Propaganda (Sendenbu) juga menyadari akan pentingkan propaganda melalui perfilman. Sebelumnya sudah dimiliki gedung-gedung bioskop dibeberapa wilayah, tetapi setelah Jepang berkuasa di Hindia-Belanda, gedung bioskop tersebut disita oleh Jepang. Segera setelah menguasai Hindia-Belanda Sendenbu membuat organisasi bawahan yang dinamakan Jawa Eiga Kosha (Perusahaan Film Jawa) yang dikepalai oleh Oya Soichi, seseorang yang bekerja dalam staf Sendenbu. Tetapi, peraturan sementara tersebut diperbaiki atas dasar Nanpo Eiga Kosaku Yoryo (Kerangka Propaganda Film di WilayahWilayah Selatan) yang dikeluarkan oleh Pemerintah Tokyo tahun 1942. Kebijakan pemerintah Tokyo untuk mengeluarkan aturan tersebut adalah untuk merumuskan suatu kebijakan pemutaran film yang terpadu bagi seluruh wilayah pendudukan Jepang di Asia Tenggara.

Di dalam kebijakan tersebut diputuskan pula, industry perfilman harus dipercayakan pada Nichi'ei (Perusahaan Film Jepang) dan Eihai (Perusahaan Distribusi Film Jepang). Perusahaan-perusahaan film ini dibentuk pada tahun 1941 atas inisiatif Pemerintah Jepang dan memiliki kantor pusat di Tokyo. Kedua perusahaan membentuk cabangnya di Jakarta. Jawa Eiga Kosha akhirnya dibubarkan setelah adanya dua perusahaan film tersebut (Kurasawa, 2015). Pada awal-awal pendudukan Jepang di Indonesia, film-film dari negara- 
negara musuh masih diperbolehkan untuk diputar, hal ini merupakan taktik Jepang untuk membujuk dan mendekati rakyat secara perlahan agar bersedia menerima kedatangan Jepang di Indonesia dan setelah beberapa waktu, film-film tersebut digantikan dengan film Jepang dan mengeluarkan larangan pemutaran film dari negara musuh. Sejumlah 52 film Jepang diimpor setiap tahun dari Jepang. Selama pendudukan Jepang, hampir seluruhnya adalah film-film Jepang dan hanya film-film yang berguna untuk propaganda saja yang diputar.
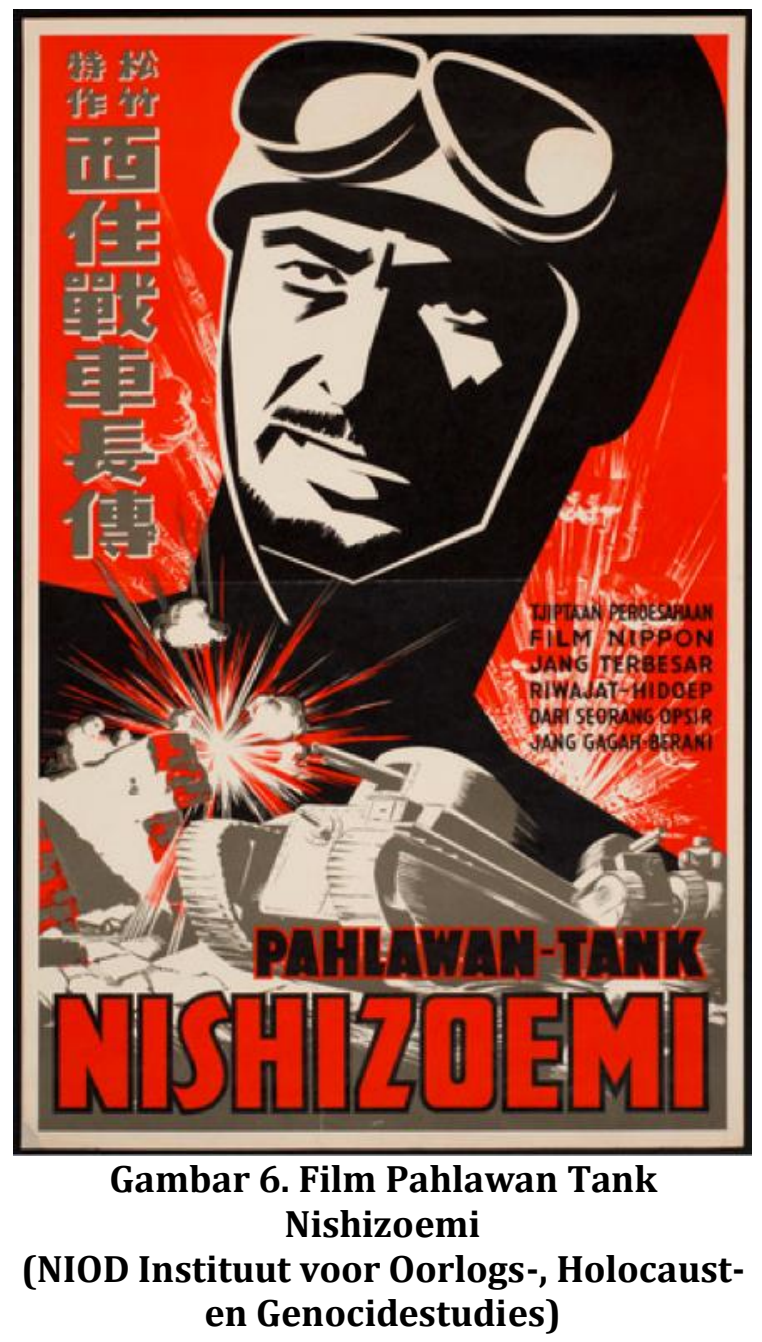

Film yang mengandung prinsip-prinsip pemerintahan disebut kokusaku eiga (film kebijakan nasional) dan mendapat rekomendasi khsus dari Pemerinatah Jepang, menurut Aiko Kurasawa ada beberapa jenis/genre film yang dipertontonkan, antara lain: (1) Film tentang persahabatan antara Jepang dan bangsa-bangsa Asia; (2) Film yang mengandung unsur-unsur nasionalisme dan patriotism kepada bangsa; (3) Film tentang operasi dan kekuatan militer Jepang; (4) Film yang menggambarkan kejahatan bangsa Barat; (5) Filmfilm yang mengajarkan tentang moral, seperti: pengorbanan diri, kasih sayang ibu, penghormatan kepada orang tua, persahabatan, sikap kewanitaan, kerajinan, dan kesetian 
yang semuanya berdasarkan nilai-nilai Jepang; dan (6) Film yang menekankan kampanye perang. Tema-tema film tersebut diatur oleh Sendenbu, jadi seorang pengarang film dari Nichi'ei membuat synopsis setelah itu diserahkan kepada Sendenbu untuk dilakukan sensor. Setelah lolos sensor, maka dibuatlah film tersebut secara utuh dan siap untuk didistribusikan. Lebih detailnya Aiko Kurasawa menjelaskan tema-tema dari film propaganda tersebut, berikut ini adalah tema-tema film propaganda Jepang: (1) Film tentang peningkatan perekonomian: Bekerdja, Romusha, Karung Goni di Jawa, Menanam Kapas, Mari Menggandakan Hasil Jarak, Penanaman Bibit, Kerja Gembira, Ubi Jalur, dan Menggarap Sawah; (2) Film tentang penyeruan pertahanan Tanah Air: Pemakaran Tombak Bamboe, Djagalah Tanah Djawa, Pendjagaan Rakjat oentoek Membela Tanah Air, Tentara Pembela, Heiho Angkatan Laut; (3) Film propaganda untuk menjaga kesehatan: Rajio Taiso, Kesehatan Badan, Pembasmi Malaria; dan (4) Film dengan nuansa politik: Jawa no Tenchosetsu, Menujoe ke Arah Mangambil Bagian Pemerintahan dalam Negeri, Indonesia Raya, Toa no Yoi Kodomo (Kurasawa, 2016).

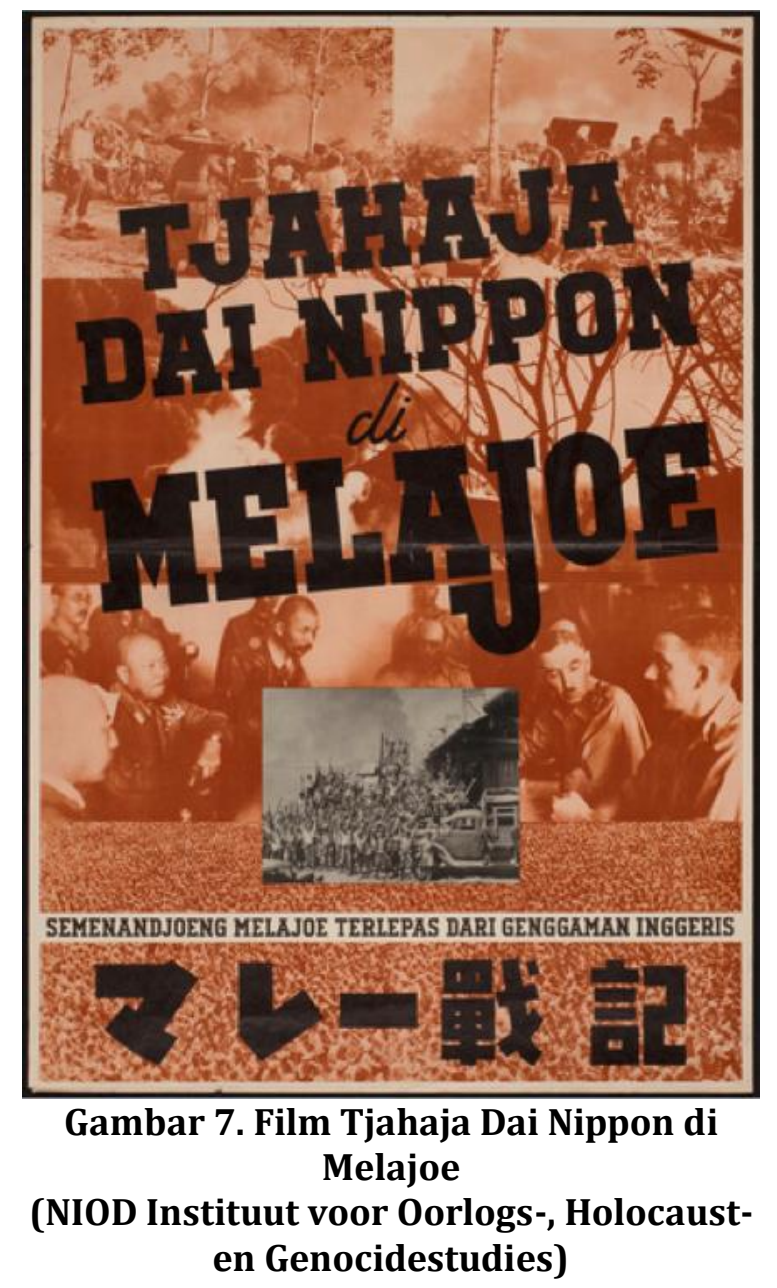


Pemutaran film-film tersebut dilakukan di bioskop-bioskop yang telah disita oleh Jepang. Pada saat itu gedung bioskop memang sudah ada, tetapi jumlahnya sangat sedikit dan tidak bisa menampung seluruh masyarakat. Sehingga, Pemerintah Militer Jepang memiliki inisiatif untuk mengadakan pemutaran film keliling atau bioskop keliling. Hal ini mudah sekali dilakukan oleh Jepang, karena di negara Jepang sendiri telah sering dilakukan pemutaran film keliling. Petugas yang terdiri dari angota staf Jawa Eiha, pegawai Sendenbu, penerjemah, dan sopir truk berkeliling dari desa ke desa dengan membawa proyektor, generator, dan film di atas truk. Film berjudul Hawai Mare Oki Kaisen berhasil diputar dilebih dari 220 tempat di Jawa. Film ini merupakan film hitam-putih yang diproduksi pada 1942 atau selama Perang Dunia II dan disutradarai oleh Kajiro Yamamoto. Film ini menggambarkan semangat Angkatan Laut Kekaisaran Jepang dalam perang di Pearl Harbor (Anderson, Anderson, \& Richie, 1982).

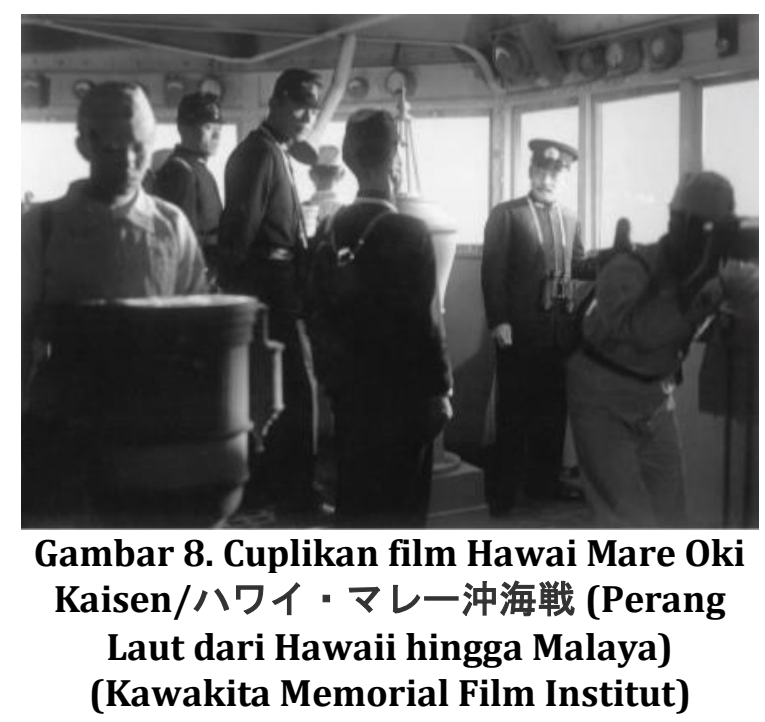

Perjalanan bioskop keliling ini ditujukan untuk semua kalangan atau untuk penonton umum dan untuk mempermudah pemahaman atas film-film yang diputar, maka ditambahkanlah teks berbahasa Indonesia dalam film. Sedangkan untuk orang-orang yang buta huruf, disediakan penerjemah yang akan menjelaskan isi film. Selama pendudukan Jepang di Hindia-Belanda, Pemerintah Militer Jepang berusaha untuk memanfaatkan dan melakukan eksploitasi sumber daya alam maupun sumber daya manusia. Sehingga Sendenbu juga memiliki tugas yang penting dalam hal ini. Serdadu Jepang yang melakukan pertempuran pasti akan membutuhkan sarana dan prasarana, sehingga untuk mendukung terciptanya sarana dan prasarana tersebut lahirlah Romusha yang sebagian besar diambil dari penduduk pribumi Hindia-Belanda (Oktorino, 2016). Romusha ini adalah seseorang yang dituntut untuk melakukan kerja paksa. Untuk menarik hati rakyat, Pemerintah Militer Jepang memberikan janji-janji menarik, seperti: uang transportasi, gaji yang besar, tempat 
tinggal dan makanan, masa kerja 3 bulan, dan lain-lain. Tetapi, janji-janji itu tidak dipertahankan, sehingga memunculkan hal yang lebih buruk, banyak orang-orang yang diambil secara paksa di tengah jalan untuk dijadikan Romusha. Banyak diantara para Romusha mati karena kelaparan dan penyakit, selain itu banyak juga yang mati karena terkena dampak perang dengan sekutu atau sengaja dibunuh oleh tentara Jepang karena melakukan kesalahan atau setelah menyelesaikan instalasi militer rahasia.

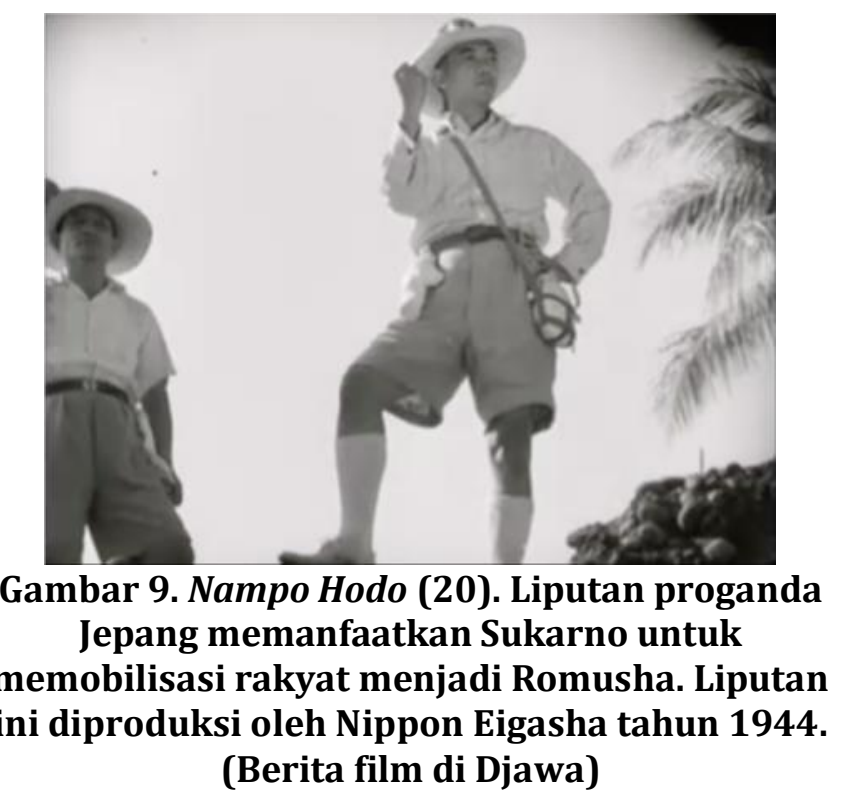

Sekitar 2,6 juta orang menjadi Romusha dan puluhan hingga ratusan ribu orang meninggal. Para Romusha ini tidak hanya ditempatkan di wilayah Indonesia saja, melainkan dibeberapa tempat di wilayah Asia Tenggara, seperti: Birma, Malaya, Siam, Filipina, dan ada pula yang dibawa kekepulauan Solomon. Jepang sendiri memiliki rencana besar, yakni menghubungkan seluruh Asia Timur Raya dari Manchuria ke Singapura melalui rel kereta api. Pembangunan ini dilaksanakan dalam waktu yang sangat singkat di daerah hutan dan menggunakan cara yang manual, sehingga kebutuhan akan tenaga kerja sangat banyak. Romusha dari Jawa juga tidak luput dari penugasan tersebut, tercatat kurang lebih 300.000 Romusha di kirim keluar Jawa (Kurasawa, 2016). Seperti apa yang telah dijelaskan di atas, para romusha dipaksa untuk bekerja tidak hanya di wilayah Indonesia, tetapi juga dikirim ke wilayah-wilayah lain di luar Indonesia.

Berikut ini adalah tugas dan pemanfaatan tenaga kerja romusha: (1) Menyelenggarakan pekerjaan yang berhubungan dengan kepentingan bala tentara dan pembela tanah air; (2) Memperbaiki dan menambah produksi bahan keperluan bala tentara, persenjataan, dan lain-lain; (3) Menambah penghasilan bahan makanan yang penting; (4) Menyelenggarakan pengangkutan dan perhubungan; dan (5) Pekerjaan penting lainnya pada 
masa perang (pembangunan infrastruktur, lapangan terbang, benteng pantai, lubang perlindungan, parit perlindungan, pabrik amunisi dan lain-lain yang sekiranya membutuhkan pekerjaan berat) (Kurasawa, 2015). Kehidupan para romusha sangat tragis, mereka diperlakukan secara tidak manusiawi. Di atas juga telah dijelaskan banyak dari romusha yang kehilangan nyawa dalam bekerja, bahkan sebelum bekerja pun juga ada yang meninggal karena kondisi transportasi yang sangat buruk. Tempat kerja para romusha terletak di tempat yang sangat jauh dan wilayah yang tidak berpenghuni. Penyakit-penyakit menular pun juga diderita oleh para romusha. Tempat tinggal romusha hanya terbuat dari bambu dan kayu. Kecelakaan kerja yang menimbulkan cedera sampai kematian sangat sering terjadi, seperti terjatuh atau terkena ledakan dinamit. Selain untuk bekerja, para romusha juga dijadika kelinci percobaan. Di Jakarta, sekitar 900 romusha yang akan diberangkatkan ke luar Jawa mati mengenaskan karena suntikan tetanus yang diberikan oleh ilmuwan Jepang.

\section{Kesimpulan}

Kemenangan Jepang atas serangan yang dilakukannya di Pearl Harbor dan Malaya membuka jalan lebar Jepang untuk menuju ke Hindia-Belanda. Wilayah Tarakan di Kalimantan Utara merupakan wilayah pertama Hindia-Belanda yang dapat diduduki oleh Jepang. Dari kawasan utara Hindia-Belanda, Jepang meorganisasikan kekuatannya untuk melakukan serangan ke wilayah selatan atau Jawa yang saat itu menjadi pusat pemerintahan Hindia-Belanda. Pada awal Februari 1942, unit udara militer Jepang melakukan serangan pembukaan ke Jawa Timur. Akhir Februari terjadi pertempuran laut di Laut Jawa antara Armada Laut Jepang melawan Armada Laut Sekutu. Kemenangan Armada Laut Jepang ini memudahkannya untuk mendaratkan pasukan-pasukannya di Jawa. Belanda pun harus mengakui kekuatan Jepang dengan menyetujui Perjanjian Kalijati. Dalam suatu peperangan, propaganda tidak dapat dipisahkan, dapat diibaratkan bahwa perang dan propaganda bagaikan dua sisi mata yang yang saling melengkapi. Sendenbu atau organisasi propaganda Jepang di Indonesia memiliki tanggung jawab untuk menjalankan propaganda.

Berberapa media propaganda yang digunakan oleh Jepang saat itu yakni poster dan film. Propaganda melalui poster dan film tidak asal pilih tetapi disesuaikan dengan kondisi masyarakat Indonesia pada saat itu. Maksud Jepang menggunakan dua media tersebut karena pada saat itu banyak dari penduduk Indonesia masih belum bisa membaca (terutama di wilayah pedesaan), meskipun ada itu pun hanya sedikit (terutama di wilayah kota), sehingga media poster dan film dianggap efektif untuk mempengaruhi penduduk agar menerima dan membantu Jepang dalam Perang Asia Timur secara langsung dan tidak langsung. Beberapa poster yang dipublikasikan antara lain Poster 3A, Djawa Hokokai, PETA 
(Pembela Tanah Air), Heiho, dan ajakan menggunakan bahasa Jepang. Sedangkan film-film yang pernah ditayangkan yakni Nishizoemi, Tjahaja Dai Nippon di Melajoe, Hawai Mare Oki Kaisen, dan film-film liputan yang menayangkan dan memanfaatkan para elit Indonesia.

\section{Daftar Pustaka}

Anderson, J. I., Anderson, J. L., \& Richie, D. (1982). The Japanese film: Art and industry. Princeton University Press.

Aziz, M. A. (2012). Japan's colonialism and Indonesia (Vol. 1). Springer Science \& Business Media.

Berita film di Djawa. (1 Januari 1944). Nampō Hōdō (20). Nippon Eigasha Djakarta. Nomor ID 119633.

Cangara, H. (2000). Pengantar ilmu komunikasi. PT RajaGrafindo Persada.

Gorman, J. L. (2009). Pearl Harbor: A Primary Source History. Gareth Stevens.

Groen, P. (2016). The Invasion of the Dutch East Indies: An Impressive Japanese Source. International Journal of Military History and Historiography, 36(1), 49-58.

Gross, J. J., \& Levenson, R. W. (1995). Emotion elicitation using films. Cognition \& Emotion, 9(1), 87-108.

Ham, O. H. (1989). Runtuhnya Hindia Belanda. PT. Gramedia.

Jonassen, D. H. (2004). Handbook of research on educational communications and technology. Taylor \& Francis.

Jowett, G. S., \& O'donnell, V. (2018). Propaganda \& persuasion. Sage publications.

Kan Pō, Nomor 1, Tahun ke-1, Bulan 8-2602/1942.

Kan Pō, Nomor Istimewa, 7-3-2602/1942.

Kawakita Memorial Film Institut. Kajirō Yamamoto (Director.). (1942). Hawai Mare Oki Kaisen (ハワイ・マレー沖海戦). Toho Co., Ltd.

Kuntowijoyo, D. R. (2005). Pengantar ilmu sejarah. Bentang Pustaka.

Kurasawa, A. (2015). Kuasa Jepang di Jawa: Perubahan sosial di pedesaan 1942-1945. Komunitas Bambu.

Kurasawa, A. (2016). Masyarakat dan Perang Asia Timur Raya. Depok: Komunitas Bambu.

Mahaney, D. C. (2002). Propaganda posters. OAH Magazine of History, 16(3), 41-46.

NIOD. (1940). Pahlawan-Tank Nishizoemi. ID Gambar 105500.

NIOD. (1941). Tjahaja dai Nippon di Melajoe. ID Gambar 105984.

NIOD. (1942). Tjahaja Nippon Pelindoeng Nippon Pemimpin Nippon Asia. ID Gambar 102082.

NIOD. (1943). Baik orang dewasa maoepoen kanak2 marilah berbitjara dalam bahasa Nippon. Bahasa Nippon, bahasa Asia Timoer Raja!. ID Gambar 104198.

NIOD. (1943). Saja berdjoeang dalam tentara pembela tanah air. Ikoetlah!. ID Gambar 104186.

NIOD. (1944). Djawa Hokokai Himpoenan Kebaktian Rakjat. ID Gambar 105353.

NIOD. (Tweede Wereldoorlog). Heiho saja angkatan laoet. Mari serta dalam pembelaan tanah air. ID Gambar 104122.

Notosusanto, N., \& Djoened, M. (2008). Sejarah Nasional Indonesia Jilid VI: Zaman Jepang dan Zaman Republik Indonesia. Jakarta: Balai Pustaka.

Oktorino, N. (2016). Di Bawah Matahari Terbit: Sejarah Pendudukan Jepang di Indonesia 1941-1945. Jakarta: PT Gramedia.

Overy, R. (2010). War in the Pacific. Osprey Publishing.

Perez, L. G. (2013). Japan at war: an encyclopedia. ABC-CLIO. 
Remmelink, W. (2018). The Operations of the Navy in the Dutch East Indies and the Bay of Bengal. Leiden University Press.

Ricklefs, M. C. (2005). Sejarah Indonesia Modern, 1200-2004. Penerbit Serambi.

Sadiman, A. (1993). Media pendidikan: Pengertian, pengembangan, dan pemanfaatan. Jakarta: Grafindo Pers.

Sobur, A. (2001). Analisis teks media: suatu pengantar untuk analisis wacana, analisis semiotik dan analisis framing. Remaja Rosdakarya.

The Sydney Morning Herald, Japanese Invade Java at Three Points, Edisi Senin 2 Maret 1942, Lembar ke-1 dan ke-5.

Yenne, B. (2014). The Imperial Japanese Army: The Invincible Years 1941-42. Bloomsbury Publishing.

Yoshiaki, Y. (2015). Grassroots Fascism: The War Experience of the Japanese People. Columbia University Press. 